* Mestre em Direito Administrativo pela Universidade Federal de Minas Gerais. Doutora em Direito Público pela mesma Casa .Professora Adjunta de Direito Constitucional e Administrativo da Universidade Federal de Juiz de Fora, Pesquisadora, Professora do Mestrado em Direito e Inovações da Faculdade de Direito da UFJF e ex-Procuradora do Município de Juiz de Fora. lg.melquiades@uol.com.br.

** Mestranda em Direito e Inovação pela Universidade Federal de Juiz de Fora. Graduada em Direito pela Universidade Federal de Juiz de Fora. pri_calegari@hotmail.com

*** Mestre em Direito e Inovação pela Universidade Federal de Juiz de Fora (UFJF). Mestre em Hermenêutica e Direitos Fundamentais pela Universidade Presidente Antônio Carlos. Pós-graduação lato sensu em Direito Constitucional Aplicado. Advogada. Graduada pelo Instituto Vianna Júnior. Bacharel em Comunicação Social/Jornalismo pela UFJF.

marianacolucciadv@gmail. com

\section{O Direito Administrativo sob a Égide do Pós-Positivismo}

\author{
The Administrative Law Under the Aegis \\ of Post-PositivisM
}

\section{Luciana Gaspar Melquíades Duarte* Priscila de Oliveira Calegari** Mariana Colucci Goulart Martins****}

Como citar: DUARTE, Luciana Gaspar Melquíades. CALEGARI, Priscila de Oliveira. MARTINS, Mariana Colucci Goulart Martins. $\mathrm{O}$ direito administrativo sob a égide do póspositivismo. Revista do Direito Público, Londrina, v. 12, n. 2, p. 183-215, ago. 2017. DOI: $10.5433 / 1980-511 X .2017 v 12 n 2 p 183$

Resumo: O presente artigo almeja analisar o direito administrativo sob a égide do póspositivismo, destacando alguns de seus principais institutos. Desse modo, discutir-se-á sobre o conceito e o objetivo desse ramo jurídico conforme o olhar pós-positivista, enfatizando os princípios da legalidade, da supremacia do interesse público sobre o interesse particular e da discricionariedade administrativa, sempre de forma crítica. Além disso, algumas questões acerca dos direitos fundamentais no âmbito do direito administrativo pós-positivista serão abordadas através de análise de alguns julgamentos do Supremo Tribunal Federal (STF) brasileiro, nomeadamente o Recurso Extraordinário (RE) n 440.028/SP e a Arguição 
de Descumprimento de Preceito Fundamental (ADPF) $\mathrm{n}^{\circ} 186$.

Palavras-chave: Direito administrativo. Póspositivismo. Direitos fundamentais.

Abstract: This study analyzes Administrative Law under the aegis of post-positivism; highlights its major institutes; and discusses its legal concepts and objectives through a postpositivism approach. In addition, this paper explores, in a critical manner, the importance of the following principles: legality, supremacy of public interest over private interest, and administrative discretion. Moreover, this research investigates fundamental rights within the scope of the post-positivist administrative law and analyzes decisions of the Brazilian Supreme Court (i.e., Supremo Tribunal Federal), giving special attention to the extraordinary appeal n. 440.028/SP and the allegation of breach of the fundamental precept n. 186 ..

Key words: Administrative law. Postpositivism. Fundamental rights 


\section{INTRODUÇÃO}

Após a Segunda Guerra Mundial e as consequentes atrocidades vivenciadas pelos seres humanos, o mundo jurídico percebeu a importância dos valores sociais para a concretização da justiça. A visão positivista baseada na crença de que apenas o processo legislativo era capaz de produzir o bom Direito muitas vezes sacrificou a justiça material e, por isso, ensejou o nascimento de outras perspectivas jusfilosóficas.

Em resposta aos problemas enfrentados pela concepção positivista, estruturou-se a teoria do pós-positivismo, que trouxe para o epicentro da ciência jurídica uma maior atenção às necessidades de proteção e de concretização dos direitos fundamentais. O reconhecimento dos valores e princípios constitucionais conduz a um novo olhar sobre todos os ramos da ciência jurídica, o que abarca o Direito Administrativo.

O Direito Administrativo rege o exercício das funções administrativas e sua concepção equivocada pode ser instrumento para instauração de injustiças. Diante disso, o presente artigo busca repensar o papel deste ramo da ciência jurídica, bem como os seus princípios fundantes.

Trata-se, portanto, de uma proposta de extrema relevância para a atualidade, uma vez que objetiva revisitar as origens dessa importante ciência jurídica e demonstrar como a incidência do referencial teórico pós-positivista pode impactar a forma de agir da administração pública.

Na condução da pesquisa qualitativa ora relatada, foram utilizadas fontes próprias do Direito, como normas jurídicas, jurisprudência e obras teóricas. Realizou-se, sob a metodologia dedutiva, uma revisão literária fundada nas obras dos autores pós-positivistas e dos autores da doutrina clássica do Direito Administrativo, com a pretensão de construir uma 
argumentação capaz de, ao final, demonstrar o atrelamento da atuação administrativa aos direitos fundamentais sob a égide do pós-positivismo.

\section{ALGUMAS CONSIDERAÇÕES SOBRE O PÓS-POSITIVISMO}

Desde a antiga Grécia, havia uma dicotomia no Direito: enquanto os socráticos defendiam um direito natural, vinculado à moral $\mathrm{e}$ aos valores; os sofistas alegavam não existir um direito universal, eterno, imutável, superior ao direito humano, sendo que o direito posto pelos governantes - o direito positivo - e deveria ser o legítimo.

Esta bipartição perpassou a História, mas, a partir das revoluções liberais do século XIX, o direito positivo ganhou ênfase na construção da dogmática jurídica.

Durante o baluarte do positivismo jurídico não havia outra referência jurídica senão a lei que, considerada sob seu aspecto formal, era a única e verdadeira fonte do Direito.

Kelsen (1998) deixou claro que o Direito só se tornaria autônomo a partir de uma separação do jurídico e do não jurídico. A ciência jurídica deveria se prestar a estudar somente a norma jurídica em suas estruturas, jamais no seu conteúdo. Assim, a moral, a ética e a justiça não eram consideradas integrantes da seara jurídica.

A partir da segunda metade do século XX, surgiu o póspositivismo, como uma resposta aos problemas enfrentados pela visão puramente positivista do Direito. Trata-se de um movimento jus-filosófico que ainda está em construção, mas que ganhou força, justamente por perceber que o apego excessivo à lei escrita, como única razão de ser do Direito, poderia legitimar barbáries como as ocorridas nos regimes nazista e fascista. 
O pós-positivismo emergiu sem, contudo, romper bruscamente com o positivismo jurídico. A visão daquele vai além da legalidade estrita, mas sem desprezar o direito posto.

Através da ótica pós-positivista, passou-se a compreender que o Direito deve estar atrelado a um forte caráter humanitário. A interpretação e a aplicação do ordenamento jurídico deveriam ser inspiradas por uma teoria da justiça e buscar a proteção e a concretização dos direitos fundamentais (BARROSO, 2007). Admitiu-se a pluralidade e complexidade da sociedade e, por isso mesmo, buscou-se uma abertura valorativa de todo o sistema jurídico.

Há a consideração dos princípios como "mandamentos de otimização" (ALEXY, 2015) norteados pelos valores da comunidade que passam, então, a ter sua normatividade reconhecida. Ao mesmo tempo, identifica-se a necessidade de ponderação desses princípios no caso concreto (ALEXY, 2015), sempre dentro de uma lógica racional, que visa evitar o subjetivismo, nos ditames propostos pela teoria da argumentação jurídica (ALEXY, 2001).

Pode-se dizer, portanto, que o pós-positivismo pretende revelar o peso dos direitos em uma sociedade, o que pode ser caracterizado como um trabalho "hercúleo" (DWORKIN, 2002).

Dentro da proposta pós-positivista de reconhecimento dos valores e princípios que regem a comunidade e de concretização dos direitos fundamentais, faz-se necessária uma nova análise da função a ser desempenhada pelo Direito Administrativo, bem como do seu papel nos dias de hoje.

\subsection{O Pós-positivismo no Brasil}


Conforme anteriormente mencionado, o pós-positivismo não rompe com o positivismo jurídico para voltar aos ideais jusnaturalistas. Na verdade, busca-se uma conciliação entre dois dos mais caros princípios http://www. sintese.com/doutrina_integra.asp?id=1207 - _ftn4 para a ordem jurídica: a justiça e a segurança jurídica.

Durante muito tempo, essa dicotomia entre justiça e segurança jurídica foi vista como algo insuperável pelos julgadores. No entanto, o findar da Segunda Guerra Mundial mostrou ao mundo as atrocidades que a humanidade é capaz de fazer sob o ensejo de um normativismo cego e, assim, surgiu a necessidade de compreender o Direito dito através dos textos legais sem abandonar os valores da sociedade e da condição humana.

Nesse sentido, consoante afirma Barroso (2007), em determinado sentido, o pós-positivismo apresenta-se como uma terceira via entre as compreensões positivista e jusnaturalista: não desconsidera a importância das demandas do Direito por clareza, certeza e objetividade, porém, não concebe o mesmo Direito como desconectado de uma filosofia moral e de uma filosofia política.

Sob a égide do pensamento positivista, a Constituição era tratada apenas como uma carta política, destituída de normatividade. A supremacia constitucional afirmada por Kelsen (1998) poderia ser qualificada como meramente formal. Contudo, o pensamento pós-positivista gera uma mudança radical na própria forma de interpretar diploma constitucional dos países.

Essa mudança começou a ocorrer na Europa, após de 1948. Já no Brasil, apenas após a Constituição de 1988, a prática jurídica passou a incorporar a efetividade das normas constitucionais carregadas de princípios que regem a comunidade política (BARROSO, 2007). Desta forma, elas passaram a, efetivamente, condicionar a atuação legislativa e administrativa, impedindo a edição de atos a elas desconformes e exigindo a prática de outros que garantissem a sua eficácia.

\subsection{As Normas Jurídicas sob a Ótica Pós-Positivista}


Dworkin (2002) critica a visão positivista que ignora os princípios sob alegação de que os mesmos seriam o ponto de contato entre o direito e a moral.

Na mesma perspectiva, Alexy (2008) acredita no reconhecimento dos princípios e destaca que eles são uma espécie de norma-jurídica. Enquanto as normas do tipo "regra" são aplicadas na base do "tudo ou nada", devendo-se fazer exatamente o que ela exige (ALEXY, 2015), as normas do tipo "princípio", como mandamentos de otimização devem ser aplicadas na maior medida possível a partir do emprego da técnica da proporcionalidade (ALEXY, 2015).

Diante de uma colisão principiológica em um caso concreto, o julgador deverá percorrer a máxima da proporcionalidade, que pode ser desdobrado em três máximas parciais: i) adequação, ii) necessidade e iii) proporcionalidade em sentido estrito. Portanto, dever-se-á verificar se i) é o meio utilizado é o adequado, o viável, para a persecução do fim desejado, ii) se o meio utilizado é o menos gravoso para o direito objeto de restrição e, por isso, necessário, iii) a importância da intervenção em um determinado direito fundamental, por meio de uma análise racional, argumentativa e comparativa entre os meios utilizados e os fins pretendidos.

Salienta-se que, após a ponderação, o princípio que obtiver maior peso adquirirá a estrutura de regra, devendo ser integralmente realizado diante daquele caso concreto.

Assim, demonstra-se que, no contexto pós-positivista, os princípios adquiriram uma força jamais vista, uma vez que por meio deles haverá mais uma chance de concretizar os direitos fundamentais e os ideais da justiça pretendidos. 


\section{A ORIGEM DO DIREITO ADMINISTRATIVO}

Costuma-se dizer que o Direito Administrativo surgiu na França, como decorrência da Revolução Francesa. Até o século XVIII, o Estado confundia-se com a figura do monarca absolutista e não existiam regras para tratar das relações entre administração e administrados, eis que o poder estatal era incondicionado.

Após a Revolução Francesa, preconizou-se a limitação do poder estatal. A doutrina clássica costuma narrar que o Direito Administrativo fora forjado nesse cenário, sob a crença (baseada no pensamento positivista) de que a lei seria capaz de acabar com os arbítrios do rei ao mesmo tempo em que representaria o primado da soberania popular (BINENBOJM, 2008).

O Direito Administrativo surge exatamente com o ideal de regular a conduta do Estado e mantê-la afivelada às disposições legais (MELLO, 2010), mantendo, no entanto, o entendimento de que o Estado ainda seria mais poderoso e detentor de prerrogativas especiais frente ao cidadão.

Todavia, a história demonstrou que o simples atendimento às normas formais é ineficaz para a concretização dos direitos e garantias fundamentais, impondo uma nova leitura do Direito Administrativo, na busca de um aprimoramento da aplicação da lei, consciente de que o texto legal não deve ser executado na sua literalidade sem antes observar o atendimento aos valores e princípios que permeiam a sociedade.

\section{DIREITO ADMINISTRATIVO: CONCEITO E OBJETIVO SOB O OLHAR PÓS-POSITIVISTA}


No século XIX, o autor administrativista Gianquinto (1881), ao trabalhar com o campo de atuação do Direito Administrativo, dizia que a "[...] administração em sua organização está coordenada a um sistema de leis: encontramo-nos aqui diante do Direito Administrativo".

Pontes (1968) afirmava ser o Direito Administrativo o conjunto das normas que regulam a atividade administrativa em sentidos formal e material. Desse modo, o Direito Administrativo seria o ramo do direito público que trata da administração pública em todos os setores da atividade estatal, tanto no poder Executivo quanto nos demais poderes do Estado.

Já Mello (2010, p. 29) definia o Direito Administrativo como “[...] ramo do Direito Público que disciplina o exercício da função administrativa, bem como pessoas e órgãos que a desempenham".

Como é possível observar em todas as definições acima transcritas, a doutrina clássica ainda é fortemente baseada na concepção positivista, atrelada às disposições legais. O Direito Administrativo é visto como um conjunto de normas, um conjunto de regras, que disciplinam a função e organização do Estado.

Os conceitos apresentados, em momento algum, mencionam a importância, para o Direito Administrativo, dos princípios e dos valores sociais que norteiam a Constituição.

\subsection{A Concepção Pós-positivista de Direito Administrativo e Seus Escopos}

Há necessidade de revisão da doutrina administrativista no Brasil, uma vez que ela se encontra ainda permeada por concepções antidemocráticas inerentes a um passado de viés fortemente autoritário. 
Não é surpreendente que a atividade administrativa ainda reflita entendimentos personalistas ou eminentemente baseados na legalidade estrita.

Binenbojm (2008) aduz que, em um passado não muito distante, a Constituição não era sequer considerada como autêntica norma jurídica e, por conseguinte, nem dotada de cogência e imperatividade, era tão somente uma proclamação retórica de valores e de diretrizes políticas. Impunha-se, pois, que os preceitos constitucionais verdadeiramente inspirassem o legislador, e que fossem aplicados diretamente pelos magistrados e demais operadores do Direito na resolução de controvérsias judiciais.

Portanto, o Direito experimentou um processo de constitucionalização, iniciado, sobretudo após os absurdos do nazifascismo. O reconhecimento do caráter normativo dos princípios constitucionais sepultou o emprego da metodologia mecanicista, asséptica aos valores e baseada apenas na subsunção. A partir desse entendimento, configurou-se a supremacia formal e material da Constituição, compreendendo-se que a própria legislação infraconstitucional deveria retirar sua validade da norma constitucional.

No Brasil, desenhou-se esse cenário a partir da Constituição (BRASIL, 1988), que inaugurou uma fase axiologicamente pautada na preocupação com os direitos fundamentais, o que foi transmitido a todos os ramos do Direito.

Diante do exposto, pode-se aferir que o Direito Administrativo também sofreu os impactos dos preceitos pós-positivistas. Logo, passou a ser considerada uma reunião das normas jurídicas de direito público que regem as atividades administrativas imprescindíveis à concretização dos direitos fundamentais e, ainda, à organização e ao funcionamento 
das estruturas estatais e não estatais incumbidas de seu desempenho (JUSTEN FILHO, 2010).

Ou seja, o Direito Administrativo, sob a égide do póspositivismo, preocupa-se com a consecução desses direitos e não com a mera satisfação dos interesses da Administração Pública. Esta, por sua vez, deve atuar de forma consonante às necessidades dos cidadãos, sem autoritarismos ou personalismos, mas de modo racional e condizente às inovações paradigmáticas da ordem jurídica.

\subsection{A Crise do Princípio da Legalidade}

O princípio da legalidade sempre fora considerado princípio basilar do regime jurídico-administrativo, eis que fruto da submissão do Estado à lei. A ideia precípua acerca do princípio da legalidade seria, desse modo, a contraposição às tendências personalistas dos governantes e, consequentemente, ao autoritarismo. Haveria uma concepção tradicional que aduziria ser este princípio “ [...] o antídoto natural do poder monocrático ou oligárquico, pois tem como raiz a ideia de soberania popular, de exaltação da cidadania" (MELLO, 2010, p. 100).

Percebe-se, neste sentido, que o elencado princípio, com essa interpretação, condizente ao contexto positivista, é concebido como capaz de solucionar potenciais vontades autoritárias dos governantes, que seriam tolhidos de seus anseios dominantes pela exigência do respeito à lei.

Sabe-se, todavia, que na realidade não é o que ocorre, uma vez que as leis não são necessariamente justas, ainda que concebidas de modo formalmente correto. Desse modo, não é em razão do mero respeito àquelas que restará configurado o respeito pela justiça e pelo bem comum. 
A percepção de que a submissão da Administração Pública às leis pode, por si só, engendrar tais objetivos não é mais viável no contexto pós-positivista. Os exemplos das leis nazistas e fascistas servem-nos como alertas de que o conteúdo legislativo não é isento de erros e pode ser extremamente danoso aos cidadãos e à sociedade.

$\mathrm{Na}$ esteira da concepção pós-positivita, Binenbojm (2008) considera que a vinculação da Administração Pública não se circunscreve à lei formal, mas a um bloco de legalidade ou ordenamento jurídico como um conjunto de normas harmônico e coeso. Ou seja, toda a sistematização de poderes e deveres da Administração passa a ser delineada a partir dos arcabouços constitucionais pertinentes, principalmente no sistema de direitos fundamentais e nas normas estruturantes do regime democrático, em razão de sua posição axiológica central e estruturante do Estado Democrático de Direito (BINENBOJM, 2008).

Destarte, o fundamento da atuação da administração pública meramente na lei posta não se coaduna ao pós-positivismo. Nessa conjuntura, o princípio da legalidade transforma-se em regra da juridicidade, uma vez que a administração precisa atuar em harmonia com o ordenamento jurídico como um todo sistêmico (o que abarca também os princípios, as normas constitucionais, os direitos fundamentais, as finalidades públicas, entre outros).

A conformação normativa da juridicidade como regra implica sua consideração como um comando absoluto, que deve ser cumprido integralmente (ALEXY, 2008).

Cumpre ressaltar que, de acordo com Bustamante (2008), o positivismo seria uma teoria acerca do que os juízes fazem, ao passo que o pós-positivismo seria uma teoria normativa, ou seja, que os juízes deveriam fazer. Sendo assim, o positivismo acaba sendo um óbice ao 
desenvolvimento de teorias da argumentação jurídica que destacam o momento justificativo da prática jurídica e almejam estabelecer determinados critérios pragmáticos, técnicos e racionais para fundamentar as decisões e as normas individuais estabelecidas na aplicação do Direito (BUSTAMANTE, 2008).

Ou seja, no pós-positivismo deve-se não apenas aplicar uma dada lei, mas argumentar as razões para fazê-lo, de modo a diminuir ou dificultar injustiças. Nesse meandro, a argumentação jurídica é pilar da justiça e não basta justificar uma determinada decisão com base apenas em uma lei positivada.

Segundo Bustamante (2008), no pós-positivismo, a dogmática jurídica adquire a função de sistematizar e interpretar o Direito válido e de ordenar o Direito perante princípios de largo alcance, o que está quase sempre orientado por valores. As decisões jurídicas, sendo assim, devem ser racionais e não apenas um truque verbal ou uma desavença teórica. E isso “ [...] é uma forma de ingressar na prática jurídica e lutar para, sempre, melhorá-la" (BUSTAMANTE, 2008).

Não se nega a importância da lei para a atuação estatal, afinal, em um Estado Democrático de Direito as ações inerentes à Administração Pública devem ser entendidas como formalmente previstas na legislação e, devido a isso, devem ser respeitadas o máximo possível (JUSTEN FILHO, 2014) como preceitua a espécie normativa "princípio" (ALEXY, 2008). Porém, há de se reconhecer que elas, caso incorporem comandos avessos aos preceitos constitucionais, não poderão lograr aplicação, bem como que a ausência de um texto legal explícito não implica ausência de norma para o caso concreto.

\subsection{A Tensão Acerca da Supremacia do Interesse Público}


Apesar de ter sua origem marcada pelos ares revolucionários, o Direito Administrativo pouco se distanciou das práticas autoritárias cometidas pela administração pública durante o período da monarquia absolutista (BINENBOJM, 2008).

Após a queda da monarquia absolutista e a emergência do Estado de Direito, a administração, em tese, deveria representar o interesse público, o que justificava suas prerrogativas especiais frente aos particulares, bem como a discricionariedade administrativa, uma vez que representava o interesse público.

Consoante Mello (2010), o princípio da supremacia do interesse público sobre o privado é verdadeiro axioma reconhecível no atual Direito Público, apregoando a superioridade do interesse da coletividade, firmando a prevalência dele sobre o do particular, como condição da sobrevivência deste. Por conseguinte, o princípio da supremacia do interesse público é pressuposto de uma ordem social estável, em que todos e cada um possam sentir-se garantidos e resguardados.

Mello (2010) ainda afirma que, no campo da administração pública, deste princípio em tela procederiam, como consequências ou princípios subordinados, a posição privilegiada do órgão responsável por zelar pelo interesse público e de exprimi-lo nas relações com os particulares e a posição de supremacia do órgão nestas mesmas relações. Tal posição privilegiada encarnaria os supostos benefícios que a ordem jurídica conferiria em prol de assegurar a adequada proteção aos interesses públicos.

Contudo, Bandeira de Mello (2010) salienta que os efeitos dessa posição são de ordem diversa e manifestam-se em campos distintos. $\mathrm{O}$ autor cita alguns exemplos, tais como a presunção de veracidade e 
legitimidade dos atos administrativos (a qual somente vige enquanto não contendidos em juízo, ressalvados os casos expressos em lei); o benefício de prazos maiores para intervenção ao longo de processo judicial; a posição de ré, fruída pela administração, na maior parte dos feitos, transferindo- se ao particular a situação de autor com os ônus correspondentes, até mesmo os de prova; prazos especiais para prescrição das ações em que é parte o poder público, entre outros.

Assim, conforme a concepção administrativista prevalente, a supremacia do interesse público significa a sua superioridade em relação aos outros interesses também existentes em uma determinada sociedade.

De acordo com Ávila (2007), somente a um primeiro olhar seria adequada a descrição do princípio da supremacia do interesse público sobre o particular. Ainda que ele seja descrito como um princípio fundamental do direito público, elucida-se com duas específicas características. Primeiramente, ele seria um princípio jurídico, cuja função primordial seria regular as relações entre o Estado e o particular e, nesse sentido, suas supostas validade e posição hierárquica no ordenamento jurídico brasileiro permitiriam que ele fosse descoberto aprioristicamente sem exame prévio de sua referência no ordenamento jurídico.

Ainda nesse sentido, conforme Ávila (2007), o princípio em estudo não seria apenas um princípio, mas um princípio relacional, regulando a supremacia do interesse público sobre o particular, não relativamente ao funcionário público (que representa o interesse público), mas no que tange à relação entre o Estado e o particular. Sob esse aspecto, por conseguinte, o conteúdo normativo do supramencionado princípio iria pressupor a possibilidade de conflito entre os interesses público e particular no exercício da função da administração, cuja solução deveria ser em favor do primeiro. 
Essas concepções propiciam problemas de difícil superação, uma vez que há clara possibilidade de arbitrariedade, o que é ofensivo à democracia e aos direitos fundamentais.

Nesse sentido, Justen Filho (2012) afirma que anteriormente o governante adotava fórmulas dúbias, tais como o poder de império, o poder discricionário, o poder de polícia ou a natureza política do ato a fim de justificar decisões subjetivas incompatíveis com a ordem jurídica. Essas práticas foram eliminadas em razão da evolução democrática e, atualmente, o exercente do poder político refugia-se no princípio da supremacia do interesse público com a finalidade de evitar o controle ou o desfazimento de atos defeituosos, violadores de garantias constitucionais.

Contudo, o princípio da supremacia do interesse público sobre o interesse privado, em verdade nunca foi tratado com o devido cuidado pela doutrina clássica, uma vez que o interesse público sempre justificou uma busca ilimitada pelos interesses da administração (sem observar se esses interesses estavam em consonância com os direitos fundamentais).

Da mesma forma, não é possível dizer que a busca pelo interesse pelo interesse público se confunde com a busca pelo interesse da maioria, pois a maioria pode desejar que o Estado atue contra direitos fundamentais das minorias.

Para Ávila (2007), inclusive, o princípio da supremacia do interesse público sobre o particular não é sequer um princípio jurídico ou uma norma-princípio. O autor afirma isso em razão de: i) não o considerar uma norma-princípio conceitualmente, já que ele possui apenas um grau normal de aplicação, sem qualquer alusão às possibilidades normativas e concretas; ii) não o considerar uma norma-princípio normativamente, pois ele não pode ser descrito como um princípio jurídico-constitucional imanente e, ainda, iii) não o considerar capaz de, conceitual e 
normativamente, descrever uma relação de supremacia, uma vez que se a discussão for acerca da função administrativa, não pode o interesse público (ou os interesses públicos), sob o viés da atividade administrativa, ser separadamente descrito dos interesses privados.

Assim, esse princípio não poderia ser considerado como postulado explicativo do Direito Administrativo, uma vez que: (a) ele não pode ser separado ou contraposto aos interesses privados, pois estes consistem em uma parte do próprio interesse público e (b) ele não pode ser delineado sem referência a uma situação concreta "[...] e, sendo assim, em vez de um 'princípio abstrato de supremacia' ter-se-iam 'regras condicionais concretas de prevalência' (variáveis segundo o contexto)" (ÁVILLA, 2007, p. 28-29).

Seguindo a lógica pós-positivista, apenas seria possível falar em supremacia do interesse público quando esse interesse fosse correspondente a promoção e proteção dos direitos fundamentais.

Os direitos fundamentais, como se sabe, protegem não só bens coletivos, mas também bens particulares. Os direitos fundamentais de primeira dimensão protegem o particular contra o Estado (são os direitos negativos, ou direitos de liberdade). Já a segunda dimensão de direitos fundamentais prega a igualdade material entre os indivíduos (são direitos positivos). Finalmente, a terceira dimensão de direitos fundamentais consagra os direitos de solidariedade e fraternidade (SARLET, 2012). Há, ainda, autores que defendem a existência de direitos fundamentais de quarta e até mesmo de quinta dimensão.

O importante, no entanto, é demonstrar que os direitos fundamentais abarcam amplas garantias que visam sempre à preservação da dignidade humana. Desse modo, quando consoante à proteção e à promoção dos direitos fundamentais, a supremacia do interesse público 
torna-se, na verdade, uma verdadeira norma-regra que deve ser cumprida com a finalidade de buscar o bem comum.

\subsection{A Discricionariedade e a Vinculação Administrativas}

Binenbojm (2008) afirma que a palavra discricionariedade originou-se no antigo Estado europeu dos séculos XVI a XVIII, quando expressava a soberania decisória inerente ao monarca absoluto.

Apenas a partir do século XIX, com o advento do Estado de Direito, a ideia de impor limites jurídicos às atividades estatais adquiriu consistência teórica foi difundida e, por isso, a legalidade administrativa assumiu "[...] a feição de uma vinculação negativa à lei, erigindo-se a noção de discricionariedade administrativa como poder de agir da Administração nos espaços livres da regulamentação da lei" (BINENBOJM, 2008).

Entretanto, foi o Positivismo normativista kelseniano que trouxe a vinculação positiva à lei, ou seja, a concepção de que a administração pública não poderia atuar exceto se tivesse a lei como fundamento.

A discricionariedade administrativa, por seu turno, sobrevive como um local de subdeterminação normativa, dentro do qual competiria à administração exercer a sua liberdade decisória.

Porém, consoante afirma Binenbojm (2008) é possível visualizar, mesmo no século XIX, um percurso longo para cravejar parâmetros jurídicos à atividade administrativa discricionária. Nos últimos anos, percebe-se no Brasil a doutrina de discricionariedade justiciável "[...] diante do reconhecimento da eficácia normativa dos princípios jurídicos, aos quais a atuação discricionária da Administração Pública estaria diretamente vinculada" (BINENBOJM, 2008). Ou seja, o princípio da 
legalidade cedeu espaço à incidência principiológica, implicando a noção mais ampla de juridicidade.

Justen Filho (2012) considera que a melhor definição para discricionariedade é "[...] disciplina normativa da atividade da administração pública que se caracteriza pela atribuição do dever-poder de deliberar segundo a avaliação da melhor solução para o caso concreto". Sendo assim, a discricionariedade não denota que a administração pública seria titular de uma reserva teórica de poder para eleger entre distintas alternativas.

$\mathrm{Na}$ conjuntura pós-positivista, o controle sistemático dos atos da administração pública exige um juízo em nova escala em todas as fases do processo de tomada de decisões, ou seja, desde a escolha do atuar administrativo até culminar na avaliação dos efeitos primários e secundários ao longo do tempo (FREITAS, 2013).

Salienta-se que, de acordo com Freitas (2013), não há discricionariedade administrativa total, uma vez que os elementos do ato administrativo considerados como discricionários, tais como o motivo e o objeto, necessitam vincular-se ao sistema de princípios e diretos fundamentais. Devido a isso, o objeto tem que ser lícito em sentido amplo, já que os condicionamentos estatuídos pelas prioridades constitucionais afastam os extremos do Estado omisso e do Estado segurador universal.

Nesse sentido, sob a égide do pós-positivismo, é importante reconceituar a discricionariedade administrativa a fim de adequá-la ao paradigma do contemporâneo Direito Administrativo, que visa à primazia dos direitos fundamentais.

Mesmo o ato administrativo vinculado deve também ser enxergado em conformidade a este novo momento paradigmático, qual seja, o pós-positivismo. Segundo o enfoque tradicional, ato administrativo 
vinculado seria aquele em que o agente não possuiria liberdade e a ele restaria cumprir os comandos legais. Por exemplo, as licenças para edificar e as concessões de benefício previdenciário, presentes os pressupostos legais, deveriam ser conferidas pelo administrador, sem qualquer ponderação (FREITAS, 2013).

Todavia, essa acepção merece ser acolhida apenas parcialmente, já que sobrevaloriza o princípio da legalidade - já tratado no presente artigo - ao persistir que o administrador deveria observá-lo automaticamente. Freitas (2013) afirma que tal condicionamento necessita ser enxergado cautelosamente, uma vez que até nos atos vinculados subsiste liberdade ineliminável. Ou seja, é possível, naturalmente, verificar atividades administrativas fortemente vinculadas, como ocorre, por exemplo, na cobrança de tributos prevista no art. $3^{\circ}$ da Lei $n^{\circ}$ 5.172/66 (BRASIL, 1966). Porém, a vinculação é condicionada não apenas à legalidade, que espanta os juízos de conveniência, mas à totalidade dos princípios regentes das relações de administração, tais como a moralidade, prevista no art. 37 da Constituição (BRASIL, 1988), e a sustentabilidade, prevista nos arts. 225 e 170, VI da Constituição (BRASIL, 1988). O autor salienta, ainda, que a legalidade não pode conservar-se inflacionada, a ponto de permitir a erosão argumentativa (FREITAS, 2013).

Por conseguinte, não apenas os atos discricionários - mas também os atos vinculados - precisariam ser motivados de modo rigoroso: a vinculação precisa ser ponderadamente justificada.

Nesse diapasão, pretende-se realçar que tanto na prática de atos vinculados quanto de atos discricionários os sopesamentos e as ponderações coexistem com os impulsos autoritários da Administração Pública. Desse modo, pode-se aprimorar o controle dos atos administrativos, aferindo-se sua racionalidade. Portanto, pode-se 
compreender a discricionariedade administrativa legítima como uma competência - e não simples faculdade - da administração pública de avaliação e escolha das melhores consequências, mediante justificativas válidas e aceitáveis fática e juridicamente, observando-se os requisitos da efetividade do direito fundamental à boa administração pública (FREITAS, 2013).

Não é possível, conforme Freitas (2013), que a discricionariedade sirva de refúgio para arbítrios devastadores, negadores da impessoalidade e dos demais princípios, sem reação proporcional dos controles. Direitos fundamentais sociais, que transcendem a esfera individual, tal como o direito à saúde, nos termos do art. 196 da Constituição (BRASIL, 1988), continuam sendo sufocados ou precariamente atendidos, em nome da conjecturada discrição na fixação de prioridades administrativas, ainda que o núcleo essencial dos direitos fundamentais sociais seja por definição inegociável. Em razão disso, tanto os atos administrativos discricionários como os vinculados terão de ser seguidos de suas razões e, logo, o administrador estará vinculado aos fundamentos que externar e sujeito a seus termos.

Nesse enfoque, seriam evitados dois fenômenos prejudiciais: uma noção de vinculação dissociada da subordinação a princípios fundamentais e uma noção de discricionariedade tendente a não considerar as vinculações constitucional e legal, o que mina o poder de veto do sistema contra os usuais impulsos.

Sendo assim, todos os atos administrativos são controláveis. Sob esse aspecto, qualquer conduta da administração pública, seja discricionária ou vinculada, apenas será legitimada se estiver envolvida pelo primado dos princípios e dos direitos fundamentais, devendo-se aquela sempre argumentar e justificar as suas decisões, que não mais 
poderão ser dotadas de arbitrariedade.

\section{DIREITOS FUNDAMENTAIS NO ÂMBITO DO DIREITO ADMINISTRATIVO}

Na conjuntura do pós-positivismo, cabe aos direitos fundamentais nortear, de modo genérico, o funcionamento dos órgãos administrativos e a posição jurídica do particular diante da administração pública.

Pode-se destacar a liberdade e a igualdade entre os direitos fundamentais individuais, sendo ambas elementos basilares da democracia e do Estado de Direito.

$\mathrm{O}$ primeiro direito elencado manifesta-se, quanto à atividade administrativa, diante da limitação da atuação desenvolvida visando à satisfação de necessidades coletivas. O poder da administração pública e o mero apelo aos interesses públicos e coletivos não podem suprimir a liberdade individual. Portanto, de acordo com Justen Filho (2012), tal alternativa simplesmente não é compatível com o Direito, uma vez que a liberdade não pode ser suprimida mediante a invocação de interesse público determinado ou indeterminado. Por isso, o princípio da proporcionalidade deverá ser respeitado, com observância de outras garantias constitucionais e legais, quando e se for o caso de imposição de restrições.

Além disso, o Estado Democrático de Direito deve promover a liberdade, de forma ativa, a fim de assegurar que as pessoas superem restrições indevidas e injustas. Por exemplo, o direito à liberdade de locomoção exige que vias e prédios públicos sejam adequados ao deslocamento de deficientes físicos, assim como é dever estatal promover a educação de todos, de modo a não apenas assegurar a dignidade humana, 
mas inclusive propiciar o direito à liberdade de pensamento (JUSTEN FILHO, 2012).

Já a igualdade deriva da afirmação de um compromisso da atividade administrativa com a promoção da dignidade humana, inclusive por meio do tratamento isonômico. Ou seja, a isonomia é direito fundamental no sentido de que a identidade da pessoa e a realização integral de sua personalidade supõem ações e omissões do Estado proporcionadas às circunstâncias individuais.

Nesse sentido, consoante Justen Filho (2012), a isonomia jurídica consiste em promover as medidas necessárias à concretização equivalente de todos os projetos individuais e coletivos. Isso significará, eventualmente, afiançar a um indivíduo ou a um grupo a possibilidade de soluções que não são nem ansiáveis nem adequadas para outras pessoas. Cite-se, como exemplo, as cotas para acesso ao ensino universitário público e para o programa bolsa família.

As atividades administrativas terão, no contexto do póspositivismo, imposições de naturezas ativa e omissiva por aquele que as exerce e a determinação da providência adequada será dependente do exame dos meios e dos fins. Deve-se, assim, recorrer à ponderação, mencionada anteriormente no presente artigo, de modo a chegar à melhor solução para determinado caso concreto, não sendo mais possível juízos meramente apriorísticos ou friamente legalistas. A "máxima da proporcionalidade", de Alexy (2015), é o instrumento necessário para tanto.

\subsection{O Entendimento Contemporâneo do Supremo Tribunal Federal (STF)}


Em relação aos direitos fundamentais supramencionados, é interessante que se vislumbre o entendimento contemporâneo do Supremo Tribunal Federal (STF) de modo que percebamos a evolução jurisprudencial e a mudança paradigmática jurídica.

A Suprema Corte brasileira deu provimento, em outubro de 2013, ao Recurso Extraordinário (RE) n ${ }^{\circ}$ 440.028/SP (BRASIL, 2013), determinando que Estado de São Paulo realizasse reformas e adaptações necessárias na Escola Estadual Professor Vicente Teodoro de Souza, em Ribeirão Preto, a fim de garantir o pleno acesso de pessoas com deficiência (BRASIL, 2013).

Na ementa do acórdão, o Supremo Tribunal Federal (BRASIL, 2013) considerou que a Constituição (BRASIL, 1988); o Decreto ${ }^{\circ}$ 6.949 (BRASIL, 2009) - que promulgou a Convenção sobre Direitos das Pessoas com Deficiência - a Lei Federal no 7.853/89 (BRASIL, 1989); e as Leis do Estado de São Paulo no 5.500 (SÃO PAULO, 1986) e n ${ }^{\circ}$ 9.086/95 (SÃO PAULO, 1995) asseguram o direito dos portadores de necessidades especiais ao acesso a prédios públicos, devendo a Administração adotar providências que o viabilizem (BRASIL, 2013).

Sendo assim, o Relator, Ministro Marco Aurélio, no julgamento do RE $n^{\circ} 440.028 / \mathrm{SP}$, afirmou que o acórdão impugnado, advindo do Tribunal de Justiça do Estado de São Paulo (TJSP), encontra-se ementado da seguinte forma, conforme citação do eminente Ministro (BRASIL, 2013):

AÇÃO CIVIL PÚBLICA - Objetivo de condenação do Executivo na obrigação de fazer. Observância do princípio da divisão dos poderes. Em que pese a relevância da obra destinada a deficientes físicos, não cabe obrigar o Executivo a execução de obra em 
um determinado prédio da rede estadual, tornando-se diverso dos demais padronizados. Necessidade de estudo e orçamentos para que se implante o comando constitucional em toda a rede e não num determinado prédio público, com interferência caracterizada no poder de administrar do Executivo. Recurso negado, não conhecido o de ofício.

Por conseguinte, segundo o que foi trazido à baila no julgamento do $\mathrm{RE} \mathrm{n}^{\circ}$ 440.028/SP (BRASIL, 2013), compreendeu-se no acórdão alvo de recurso que seria necessário analisar a disponibilidade orçamentária do ente estatal, apesar do empenho do Ministério Público na busca pela remoção de toda e qualquer barreira física, para a plena locomoção de deficientes, a fim de que fosse permitido o acesso irrestrito de pessoas portadoras de necessidades especiais a prédios, logradouros e veículos públicos. E, desse modo, de acordo com o previsto no RE $\mathrm{n}^{\circ} 440.028 / \mathrm{SP}$, o TJSP consignou que obrigar a administração pública a realizar obras e melhorias significaria esquecer o princípio da separação dos poderes, uma vez que se trataria da efetivação de atos discricionários (BRASIL, 2013).

Todavia, conforme voto do relator do mencionado RE, a relevância do mencionado julgado seria ululante. Estaria em jogo o controle jurisdicional de políticas pública, tema que seria de grande importância para a concretização da Constituição (BRASIL, 1988), ante o conteúdo dirigente que esta estampa (BRASIL, 2013).

Afirmou também que seriam três os requisitos a viabilizar a incursão judicial nesse campo: a natureza constitucional da política pública reclamada; a existência de correlação entre ela e os direitos fundamentais e, ainda, a prova de que há omissão ou prestação deficiente pela administração pública e inexistência de justificativa razoável para 
tal comportamento (BRASIL, 2013).

Portanto, entendeu-se que a imposição quanto à acessibilidade aos prédios públicos é reforçada pelo direito à cidadania que os portadores de necessidades especiais fazem jus. A noção de república implica que a gestão pública seja efetuada por delegação e no interesse da sociedade. Obstaculizar a entrada de portadores de necessidades especiais em edifícios de uso público e áreas destinadas ao uso comum do povo implica tratá-los como cidadãos de segunda classe, o que fere o direito à igualdade e à cidadania (BRASIL, 2013).

O Ministro Marco Aurélio ainda considerou que o Estado de São Paulo em momento algum apontou políticas públicas alternativas à satisfação do encargo constitucional, inexistindo justificativa razoável para a mora administrativa. Arguiu - o Estado de São Paulo - tão somente que seria poder discricionário, o qual, conforme o relator, certamente não se estende de forma a permitir ao administrador público escolher qual preceito da Constituição (BRASIL, 1988) deseja observar (BRASIL, 2013).

Isso demonstra que o Supremo Tribunal Federal, neste caso concreto, concebeu o Direito Administrativo no contexto pós-positivista ao proteger o direito fundamental à liberdade de locomoção das pessoas portadoras de necessidades especiais, realizando, em verdade, uma ponderação entre os fins pretendidos pelo Estado Democrático de Direito e supostos anseios da administração pública.

Outro julgamento da Suprema Corte pátria que elucida o viés pós-positivista que deve ser considerado pelo Direito Administrativo e pela administração pública refere-se à Arguição de Descumprimento de Preceito Fundamental (ADPF) nº 186 (BRASIL, 2012).

Trata-se de ADPF, ajuizada pelo Partido Democrata (DEM), 
que visou à declaração de inconstitucionalidade de atos da Universidade de Brasília (UnB); do Conselho de Ensino, Pesquisa e Extensão da Universidade de Brasília (CEPE); e do Centro de Promoção de Eventos da Universidade de Brasília (CESPE). Tais entidades instituíram o sistema de reserva de vagas com base em critério étnico-racial (20\% de cotas) no processo de seleção para ingresso de estudantes no ensino superior (BRASIL, 2012).

Tal arguição foi considerada improcedente, uma vez que não se contrariaria o princípio da igualdade material, previsto no caput do art. $5^{\circ}$ da Constituição (BRASIL, 1988), diante da possibilidade de o Estado utilizar políticas universalistas, que abrangem um número indeterminado de indivíduos, mediante ações de natureza estrutural e ações afirmativas (BRASIL, 2012).

Além disso, o modelo constitucional do Brasil teria incorporado diversos mecanismos institucionais para corrigir distorções resultantes de uma aplicação apenas formal do princípio da igualdade. Portanto, medidas que almejariam reverter, no âmbito universitário, o histórico quadro de desigualdade não poderiam ser analisadas apenas à luz de sua compatibilidade com certos preceitos constitucionais isoladamente considerados, mas sim sob a ótica do arcabouço principiológico sobre o qual se assenta o Estado brasileiro (BRASIL, 2012).

Salienta-se, ainda, que de acordo com o acórdão da ADPF $\mathrm{n}^{\circ} .186$ (BRASIL, 2012), a justiça social, mais do que simplesmente redistribuir riquezas criadas pelo esforço coletivo, hoje significa distinguir, reconhecer e incorporar à sociedade mais ampla valores culturais diversificados, muitas vezes considerados inferiores àqueles reputados dominantes.

Por conseguinte, nesse histórico julgamento buscou-se garantir 
a igualdade como direito fundamental que deve ser objeto também de ações estatais e, destarte, da administração pública. Logo, foi considerado ser responsabilidade desta promover as medidas necessárias à realização de projetos individuais e coletivos (BRASIL, 2012).

Diante do exposto, pode-se notar que, sob a égide do póspositivismo, cabe ao Direito Administrativo a busca e a garantia dos direitos fundamentais, tais como a liberdade e a igualdade, de modo que os administrados sejam considerados cidadãos de forma plena.

\section{CONCLUSÃO}

Essa pesquisa buscou situar o Direito Administrativo no paradigma do pós-positivismo, pretendendo, assim, oferecer uma visão renovada da própria administração pública.

Procurou-se demonstrar que diversos institutos administrativistas estavam muito mais voltados à lógica da autoridade do que à lógica da liberdade durante o contraditório desenvolvimento do Direito Administrativo que se sucedeu nos séculos XIX e XX. Portanto, conceitos categorias tais como legalidade, interesse público e discricionariedade foram elaborados de forma a desconsiderar os direitos fundamentais. E apenas recentemente percebeu-se a grande necessidade de rediscutir esses preceitos teóricos de forma harmônica à supremacia da Constituição e à centralidade antropológica no Estado Democrático de Direito.

Nesse sentido, almejou-se destacar que, se, no positivismo, o agir administrativo era praticamente inquestionável desde que se apoiasse em pressupostos legais, no pós-positivismo, tal comportamento não mais é possível, posto que a lei deixou de ser sinônimo de justiça material. O Direito, entendido de forma sistêmica - o que inclui princípios e valores 
- assumiu o papel de bússola para o ente público.

Autoritarismo, egocentrismo e personalismo não encontram espaço neste novo contexto. No pós-positivismo, a busca pela realização plena dos direitos fundamentais dos cidadãos gerencia e guia a administração pública e não mais apenas a letra fria da lei - como prevê o clássico princípio da legalidade - ou conceitos deveras abstratos, tais como interesse público e interesse privado.

O ideário pós-positivista já descansa em algumas decisões do Superior Tribunal Federal brasileiro, conforme supracitado nos acórdãos acerca da imprescindível acessibilidade de portadores de necessidades especiais a prédios públicos e da constitucionalidade das cotas raciais em instituições públicas de ensino superior, o que indica o respeito aos direitos fundamentais e a justificação das decisões de modo argumentativo e racional. Isto implica a conclusão de que a concepção pós-positivista do Direito Administrativo milita em proveito da promoção do indivíduo enquanto centro maior da atuação estatal.

\section{REFERÊNCIAS}

ALEXY, Robert. Teoria da argumentação jurídica: a teoria do discurso racional como teoria da fundamentação jurídica. Tradução de Zilda Hutchinson Schild Silva. São Paulo: Editora Landy, 2001.

. Teoria dos direitos fundamentais. Tradução de Virgílio Afonso da Silva. São Paulo: Malheiros, 2008.

. Teoria dos direitos fundamentais. Tradução de Virgílio Afonso da Silva. São Paulo: Malheiros, 2015.

ÁVILA, Humberto. Repensando o "princípio da supremacia do 
interesse público sobre o particular". Revista Eletrônica sobre Reforma do Estado (RERE), Salvador, n. 11, p. 1-30, set./out. 2007.

BARROSO, Luis Roberto. A reconstrução democrática do direito público no Brasil. Rio de Janeiro: Renovar, 2007a.

. Neoconstitucionalismo e constitucionalização do Direito: o triunfo tardio do direito constitucional no Brasil. Boletim de Direito Administrativo, São Paulo, ano 23, n. 1, p. 20-49, jan. 2007 b.

BINENBOJM, Gustavo. Uma teoria do direito administrativo. Rio de Janeiro: Renovar, 2008.

\section{BRASIL. Constituição (1988). Constituição da República}

Federativa do Brasil. Disponível em: <http://www.planalto.gov.br/ ccivil_03/constituicao/constituicao.htm>. Acesso em: 6 jun. 2016.

. Decreto no 6.949, de 25 de agosto de 2009. Promulga

a Convenção Internacional sobre os Direitos das Pessoas com Deficiência e seu Protocolo Facultativo, assinados em Nova York, em 30 de março de 2007. Disponível em: <http://www.planalto.gov.br/ ccivil_03/_Ato2007-2010/2009/Decreto/D6949.htm>. Acesso em: $1^{\text {o }}$ nov. 2016 .

. Lei $n^{0}$ 5.172, de 25 de outubro de 1966. Dispõe sobre o Sistema Tributário Nacional e institui normas gerais de direito tributário aplicáveis à União, Estados e Municípios. Disponível em: < http://www.planalto.gov.br/ccivil_03/leis/L5172.htm>. Acesso em: 11 abr. 2017.

. Lei $\mathbf{n}^{0}$ 7.853, de 24 de outubro de 1989. Dispõe sobre o apoio às pessoas portadoras de deficiência, sua integração social, sobre a Coordenadoria Nacional para Integração da Pessoa Portadora de Deficiência - Corde, institui a tutela jurisdicional de interesses coletivos ou difusos dessas pessoas, disciplina a atuação do Ministério 
Público, define crimes, e dá outras providências. Disponível em: $<$ https://www.planalto.gov.br/ccivil_03/leis/L7853.htm>. Acesso em: 10 jun. 2016.

\section{. Supremo Tribunal Federal (STF). Arguição de}

\section{Descumprimento de Preceito Fundamental 186 Distrito Federal.}

Rel: Min. Ricardo Lewandowski. Reqte.: Partido Democratas (DEM). Intdo.(a/s) :Conselho de Ensino, Pesquisa e Extensão da Universidade de Brasília (CEPE); Reitor da Universidade de Brasília; Centro de Seleção e de Promoção de Eventos da Universidade de Brasília (CESPE/UNB). 2012. Disponível em: < http://redir.stf.jus.br/ paginadorpub/paginador.jsp?docTP $=\mathrm{TP} \&$ doc $\mathrm{ID}=6984693>$. Acesso em: 10 jun. 2015.

. Supremo Tribunal Federal (STF). Recurso Extraordinário 440.028 São Paulo.

Rel.: Min. Marco Aurélio. Recte: Ministério Público do Estado de São Paulo. Recdo: Estado de São Paulo. 2013. Disponível em: $<$ http:// www.stf.jus.br/arquivo/cms/noticianoticiastf/anexo/re_440_028.pdf >. Acesso em: 10 jun. 2015.

BUSTAMANTE, Thomas da Rosa. Uma defesa do pós-positivismo. Virtù: Revista Virtual de Filosofia Jurídica e Teoria Constitucional, Salvador, n. 2, p. 1-40, 2008.

DWORKIN, Ronald. Levando os direitos a sério. Tradução de Nelson Boeira. São Paulo: WMF Martins Fontes, 2002.

FREITAS, Juarez. Discricionariedade administrativa: o controle das prioridades constitucionais. Revista Novos Estudos Jurídicos, Itajaí, v. 18, n. 3, p. 416-434, set./dez. 2013.

GIANQUINTO, Giovanni De Gioannis. Corso di diritto publico amministrativo: professato nella regia università 
di Pisa, 1881. Disponível em: <https://books.google.com.br/ books? $\mathrm{id}=\mathrm{kpYVAAAAYAAJ \& redir}$ esc $=\mathrm{y} \& \mathrm{hl}=\mathrm{pt}-\mathrm{BR}>$. Acesso em: 22 mar. 2015.

JUSTEN FILHO, Marçal. Curso de direito administrativo. 10. ed. São Paulo: Revista dos Tribunais, 2014.

. Curso de direito administrativo. 6. ed. Belo Horizonte: Fórum, 2010.

. Curso de direito administrativo. 8. ed. Belo Horizonte: Fórum, 2012.

KELSEN, Hans. Teoria pura do direito. Tradução de João Baptista Machado. 6. ed. São Paulo: Martins Fontes, 1998.

MELLO, Celso Antônio Bandeira. Curso de direito administrativo. 27. ed. São Paulo: Malheiros, 2010.

PONTES, Valmir. Programa de direito administrativo. 2. ed. São Paulo: Sugestões Literárias S/A, 1968.

SÃO PAULO. Lei $\mathbf{n}^{0} \mathbf{5 . 5 0 0}$, de 31 de dezembro de 1986. Dá nova redação ao Artigo 1. ${ }^{\circ}$ da Lei n. 3.710, de 04 de janeiro de 1983, que estabelece condições para acesso aos edifícios públicos pelos deficientes físicos. Disponível em: <http://www.al.sp.gov.br/ repositorio/legislacao/lei/1986/lei-5500-31.12.1986.html>. Acesso em: 10 out. 2015.

. Lei $\mathbf{n}^{\circ}$ 9.086, de 03 de março de 1995. Determina aos órgãos da Administração Direta e Indireta a adequação de seus projetos, edificações, instalações e mobiliário ao uso de pessoas portadoras de deficiências. Disponível em: <http://www.al.sp.gov.br/ repositorio/legislacao/lei/1995/lei-9086-03.03.1995.html>. Acesso em: 
10 out. 2015.

SARLET, Ingo Wolfgang. A eficácia dos direitos fundamentais: uma teoria geral dos direitos fundamentais na perspectiva constitucional. 11. ed. Porto Alegre: Livraria do Advogado, 2012.

Como citar: DUARTE, Luciana Gaspar Melquíades. CALEGARI, Priscila de Oliveira. MARTINS, Mariana Colucci Goulart Martins. O direito administrativo sob a égide do pós-positivismo. Revista do Direito Público, Londrina, v. 12, n. 2, p. 183-215, ago. 2017. DOI: 10.5433/1980-511X.2017v12n2p183

Recebido em: 24/11/2016

Aprovado em: 25/04/2017 